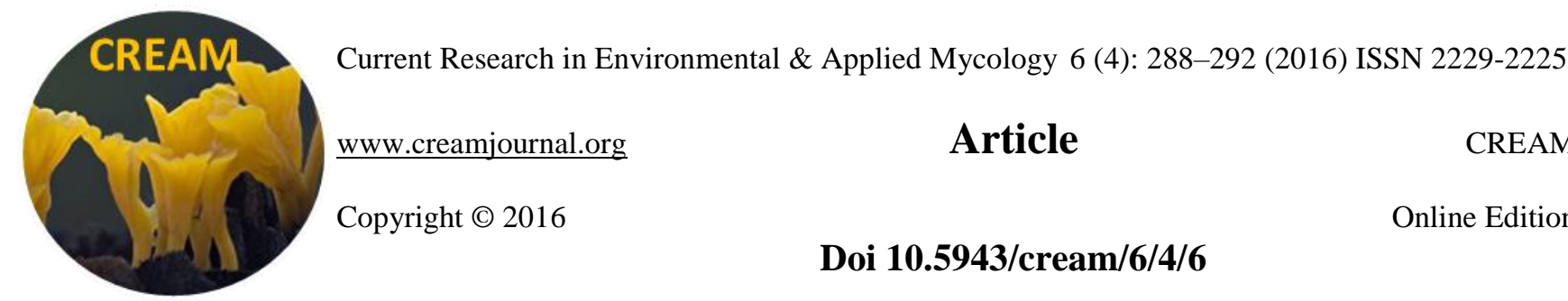

\title{
Prillieuxina citricola sp. nov. from Himachal Pradesh, India
}

\section{Gautam $\mathrm{AK}^{1}$ and Avasthi $\mathrm{S}^{2}$}

\footnotetext{
${ }^{1}$ Faculty of Science, School of Agriculture, Abhilashi University, Mandi, Himachal Pradesh, India

${ }^{2}$ Department of Botany, Abhilashi Institute of Life Sciences, Mandi, Himachal Pradesh, India
}

Gautam AK, Avasthi S 2016 - Prillieuxina citricola sp. nov. from Himachal Pradesh, India. Current Research in Environmental \& Applied Mycology 6(4), 288-292, Doi 10.5943/cream/6/4/6

\begin{abstract}
The present paper deals with a new black mildew collected on living leaves of lemon (Citrus aurantifolia, Rutaceae), from Bilaspur, Himachal Pradesh, India. The fungus was identified as the species of Prillieuxina as it contains substraight, branched hyphae without appressoria and setae; orbicular thyriothecia and brown uniseptate ascospores. A critical comparison of current taxon was carried out with species of genus Prillieuxina reported earlier on plants of the family Rutaceae and other closely similar species and found that there are no earlier reports on Citrus aurantifolia. Therefore, new species Prillieuxina citricola is described and illustrated in the present paper based on morphology and specificity of host association.
\end{abstract}

Key words - Asterinales - Black mildew - Citrus - foliicolous asexual fungi - taxonomy

\section{Introduction}

Black mildews are fungi that produce black colonies on the host surface. These fungi are thought to be host-specific, and infect mostly leaves, often soft stems and petioles. They are mostly epiphyllous, but also hypophyllous, occurring commonly in the tropics and subtropics. Black mildews require humid environments for infection initiation and development and produce various structures like mycelium, appressoria, setae, thyrothecia, pycnothyria, asci, ascospores, pycnothyriospores, perithecial appendages and consistently, brown septate ascospores (Hansford 1961, Hosagoudar \& Agarwal 2008, Hosagoudar 2012, Hongsanan et al. 2014).

Prillieuxina was established by Arnaud (1918) based on P. winteriana (三 Asterina winteriana) as the type species. It is characterized by substraight, branched mycelium devoid of appressoria and setae; orbicular thyriothecia and brown uniseptate ascospores (Hongsanan 2014). This genus has been reported on a wide range of angiosperms from tropical to subtropical regions. About 78 epithets have been reported worldwide till date (Index Fungorum 2016); of which about 12 are reported from India on the members of Aquifoliaceae ( $P$. aquifoliacearum), Clusiaceae ( $P$. garciniae), Bheemamyces $(P$. argyreiae), Ebenaceae $(P$. diospyri), Elaegnaceae $(P$. elaeagni), Gangagamyces ( $P$. polyalthiae), Menispermaceae $(P$. anamirtae), Myrsinaceae $(P$. ardisiae), Oleaceae $(P$. jasmine), Rubiaceae $(P$. ixorigena), Rutaceae(P. aeglicola) and Sterculiaceae (P. pterigotae) (Hosagoudar 2012, Gautam 2015). Aegle marmelos, Anamirta cocculus, Ardisia solancea, Argyereia sp., Diospyros malabaricus, Elaeagnus kologa, Garcinia imberti, Ilex denticulate, Ixora coccinea, Jasminum flexile, Polyalthia longifolia and Pterygota alata are reported to be infected with black mildew disease caused by different species of Prillieuxina (Hosagoudar 2012, Gautam 2014, Hongsanan et al. 2014, Gautam 2015).

Although Prillieuxina is an important genus that lacks appressoria, it is still included in the family Asterinaceae based on characters such as colonies spread on host surface, superficial 
thyriothecia, globose asci and 1-3-multi-septate ascospores. The genus mainly adopts obligate biotrophic lifestyle on living leaves and develops different heterogeneous infection strategies like expanded hypostromata, intercellular hyphae or penetration of the host stomata. There are number of thyriothecia forming fungi such as Halbania, Schenckiella and Uleothyrium which also contained mycelium devoid of appressoria. These genera differ from each other on the basis of thyriothecia, asci and ascospores. The asci were observed without an ocular chamber with 3-septate, fusiform, inequilateral and brown ascospores in genus Halibania, while elongated clavate asci with brown pseudoparaphyses containing 4-5-septate brown ascospores in Schenckiella and clavate to ellipsoidal, apedicellate with opaque thickening at apical region having straight or slightly curved, elongate fusoid, hyaline, 1-septate ascospores, parallel inside asci in Uleothyrium (Hofmann 2009, Hosagoudar 2012, Hongsanan et al. 2014). The asci formed in Schenckiella are rarely observed in the Dothideomycetes. Different dothideomycetes like Elsinoe fawcettii (Jayawardena et al. 2014), Polychaeton citri and Pseudocercospora angolensi (Schoch et al. 2009) have been reported to cause scab and anthracnose on various Citrus spp.

During November 2014, a black mildew infection was observed on leaves of Citrus aurantiolia (Christm.) Swingle. The plant contains numerous phytochemicals which exhibit anti-inflammatory, antimicrobial, anticancer and anti-oxidative activities. It is used intensively in the preparation of various juices and pickles (Tanaka 1959, Penjor et al. 2014). The detailed microscopic observations revealed structures like orbicular and astomatous thyriothecia with radiating cells and dehisce stellately at the center. The presence of mycelium devoid of appressoria and setae pointed out the relatedness of the fungus to genus Prillieuxina G. Arnaud. This fungal genus exhibits a wide diversity and host range and believed to be host specific; however, no earlier reports on C. aurantifolia are available. The aim of this study is the description of new species, based on morphology and host-specificity. The detail morphological description, colour photographs, line drawings and discussions are provided here.

\section{Materials \& Methods}

The infected leaf samples of the $C$. aurantifolia were collected in district Bilaspur of Himachal Pradesh during the course of a field survey in winter of 2014. All the collected samples were taken to laboratory and analyzed for morphological and microscopic characteristics. Field notes were prepared regarding the disease symptoms, nature of colonies, nature of infection, locality and altitude, etc. The morphological examination of diseased spots was carried out with the help of hand lenses for colour and texture. Nail polish technique was used to study the micromorphological characters of the fungi. Surface scrapings of black colonies were taken directly from infected host, mounted in $5 \% \mathrm{KOH}$ solution and then replaced by lactophenol to make the septa visible (Hosagoudar \& Kapoor 1984). Surface scrapings and sections were taken through infection spots and mounted in cotton-blue and lactophenol mount mixture for microscopic examination. Morphotaxonomical details were observed and photomicrographs were taken under CH2 Olympus light microscope equipped with a SONY DSC WX200 digital camera. Drawings of microscopic structures like mycelium, thyriothecia, asci, ascospores, pycnothyria and pycnothyriospores were made with the help of a camera-lucida under oil immersion and measurements were carried out with the help of micrometry at 1000× magnification. All measurements were given in the form: min-max (mean \pm standard deviation) and extreme sizes are omitted. Facesoffungi and MycoBank numbers are added (Jayasiri et al. 2015).

\section{Results}

\section{Taxonomy}

Prillieuxina citricola A. K. Gautam \& S. Avasthi, sp. nov. MycoBank: MB 816864

Facesoffungi Number: FoF 02663

Etymology -The specific epithet is named after the host plant species. 

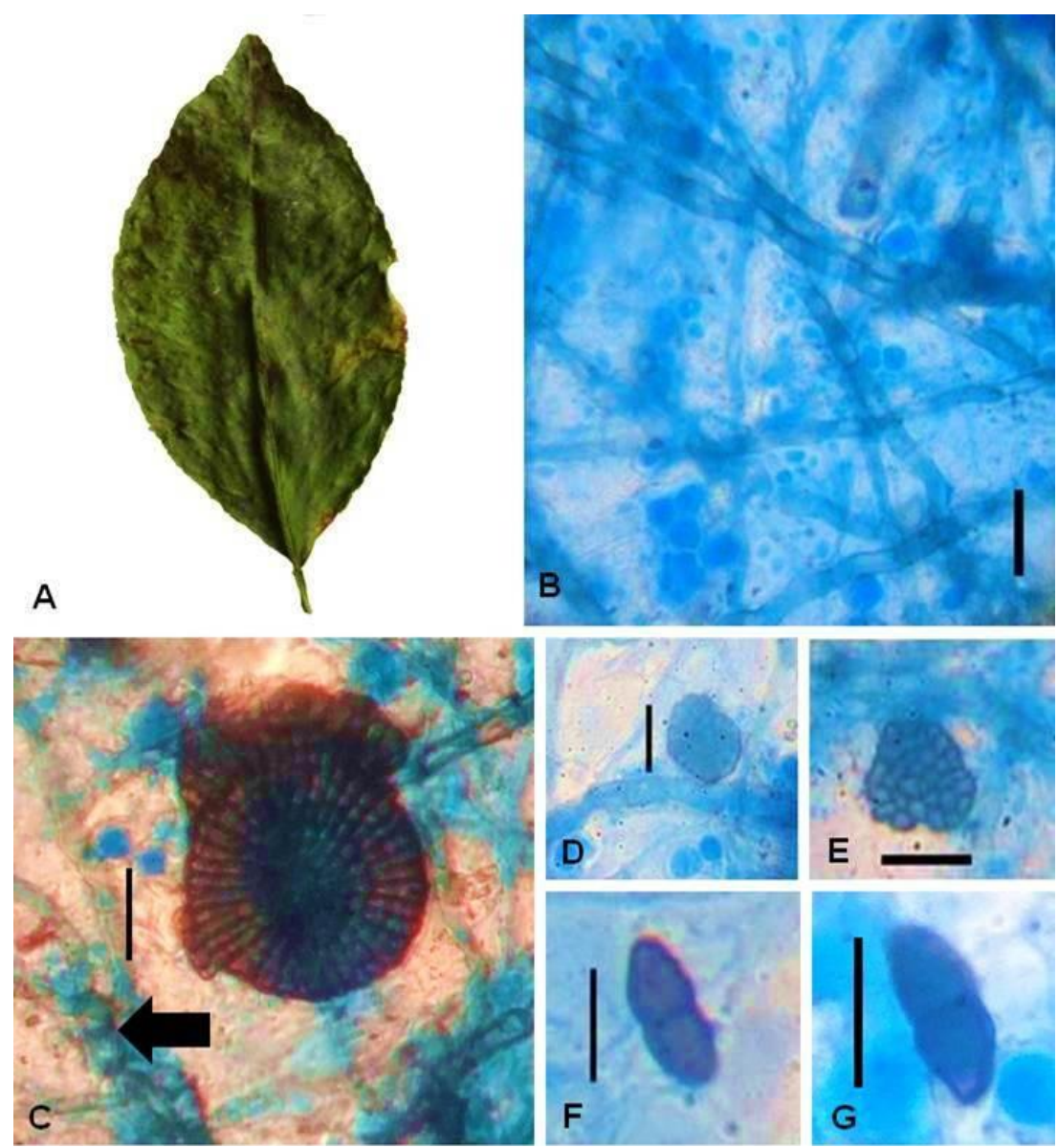

Fig. 1 - Prillieuxina citricola sp. nov. A. Black mildew infection on leaf. B. Branched mycelium. C. Thyriothecium (germinating ascospore - arrowed). D,E. Developing thyriothecia. F,G. Ascospores. Scale bars $=10 \mu \mathrm{m}$

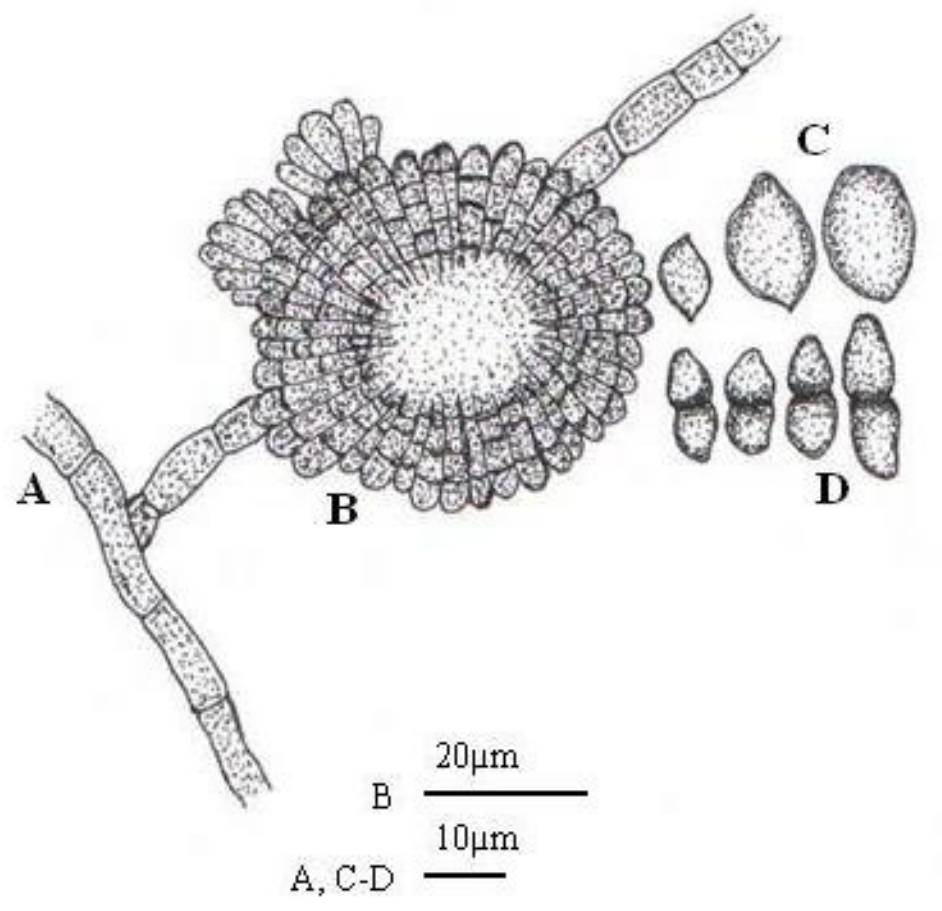

Fig. 2 - Prillieuxina citricola sp. nov. A. Branched mycelium. B. Thyriothecia with stellate dehiscence. C. Pycnothyriospores. D. Ascospores. Scale bars: A, C - D = $10 \mu \mathrm{m}, \mathrm{B}=20 \mu \mathrm{m}$. 
Table 1 Comparative account of present taxon with closely resembled Prillieuxina species on Rutaceae and some other plant families.

\begin{tabular}{|c|c|c|c|c|c|}
\hline Species & Colonies & $\begin{array}{c}\text { Thyriothecia } \\
(\mu \mathrm{m})\end{array}$ & $\begin{array}{l}\text { Asci } \\
(\mu \mathrm{m})\end{array}$ & $\begin{array}{c}\text { Ascospores } \\
(\mu \mathrm{m})\end{array}$ & Host \\
\hline Prillieuxina citricola sp. nov. & Epiphyllous & Up to 143 & 30.8 & $\begin{array}{l}11-16.5 \times 4.4- \\
6.05\end{array}$ & $\begin{array}{l}\text { Citrus } \\
\text { aurantifolia }\end{array}$ \\
\hline Prillieuxina aeglicola A. K. Gautam & $\begin{array}{l}\text { Epiphyllous to } \\
\text { hypophyllous }\end{array}$ & Up to 114 & $\begin{array}{l}\text { Up to } \\
22\end{array}$ & $\begin{array}{l}7.7-15.4 \times \\
3.3-7\end{array}$ & $\begin{array}{l}\text { Aegle } \\
\text { marmelos }\end{array}$ \\
\hline $\begin{array}{l}\text { Prillieuxina } \\
\text { aquifoliacearum Hosag., } \\
\text { Ravikumar \& Archana }\end{array}$ & Hypophyllous & Up to 192 & -- & $\begin{array}{l}16-19 \times 6- \\
10\end{array}$ & $\begin{array}{l}\text { Ilex } \\
\text { denticulata }\end{array}$ \\
\hline $\begin{array}{l}\text { Prillieuxina pterigotae Hosag. \& } \\
\text { Abraham }\end{array}$ & Hypophyllous & Up to 140 & $\begin{array}{l}\text { Up to } \\
55\end{array}$ & $26-29 \times 12-14.5$ & Pterygota alata \\
\hline $\begin{array}{l}\text { Prillieuxina polyalthiae Hosag. \& } \\
\text { Abraham }\end{array}$ & Epiphyllous & Up to 350 & $\begin{array}{l}\text { Up } \\
45\end{array}$ & $\begin{array}{l}20-23 \times 9.5- \\
11\end{array}$ & $\begin{array}{l}\text { Polyalthia } \\
\text { longifolia }\end{array}$ \\
\hline $\begin{array}{l}\text { Prillieuxina elaeagni Hosag. \& C.K. } \\
\text { Biju }\end{array}$ & Epiphyllous & Up to 235 & $\begin{array}{l}\text { Up to } \\
30\end{array}$ & $17-23 \times 9-11$ & $\begin{array}{l}\text { Elaeagnus } \\
\text { kologa }\end{array}$ \\
\hline
\end{tabular}

Colonies black, epiphyllous, dense, scattered, coalesced; hyphae superficial, substraight to crooked, branching irregular at acute angles, opposite to alternate, loosely to closely reticulate, 2.754.5 (3.42 \pm 0.84$) \mu \mathrm{m}$ wide, cells $6-11(8.58 \pm 1.72) \mu \mathrm{m}$ long; appressoria and setae absent; thyriothecia few, orbicular, scattered, up to $143(73.07 \pm 30.29) \mu \mathrm{m}$ in diameter, stellately dehisced at the centre, margin fimbriate; asci globose, ovate, octosporous, up to $30.8(23.95 \pm 4.14) \mu \mathrm{m}$ in diameter; ascospores oblong, brown, 1-septate, constricted at the septum, smooth walled, 11-16.5 (13.75 \pm 2.33 ) $\times$ 4.4-6.05 (5.1 \pm 0.82) $\mu \mathrm{m}$; pycnothyria similar to thyriothecia, scattered; pycnothyriospores brown, unicellular, pyriform, $10-16.5(13.62 \pm 2.75) \times 4.5-9(6.68 \pm 1.92) \mu \mathrm{m}$, wall smooth.

Material examined - India, Himachal Pradesh, Bilaspur, Berthin, alt. 686 m (2,495 ft), on leaves of Citrus aurantifolia (Christm.) Swingle (Rutaceae), collected A.K. Gautam, 24.11. 2014 (AUMH 1025, holotype).

\section{Discussion}

Twelve species of Prillieuxina have been reported from India of which single species i.e. $P$. aeglicola on A. marmelos was reported from the family Rutaceae (Gautam 2015). Interestingly, the infection was found associated with the colonies of Schiffnerula girijae (Gautam 2014). The present species was therefore, compared with $P$. aeglicola. As comparison with single species is not adequate to propose a new taxon, therefore, the characteristics like colonies, thyriothecia, asci, ascospores and host association of some other species of Prillieuxina were also evaluated and compared with present taxon (Table 1). Comparative analysis revealed that this species have larger thyriothecia than $P$. aeglicola. Although, the size of thyriothecia showed similarity with $P$. pterigotae but observed small size of asci and ascospores. Present species showed similarity with P. pterigotae based upon size of thyriothecia, but variable in nature of colony (hypophyllous), size of asci (up to $55 \mu \mathrm{m}$ ), ascospores $(26-29 \times 12-14.5 \mu \mathrm{m})$ and plant host (Pterygota alata). Similar sized asci were observed with $P$. elaeagni, but here again found variability with reference to size of thyriothecia (up to $235 \mu \mathrm{m}$ ), ascospores $(17-23 \times 9-11 \mu \mathrm{m})$ and plant host (Elaeagnus kologa). Similar type of comparison of present taxon with various Prillieuxina spp. is provided in Table 1. Moreover, species of genus Prillieuxina are thought to be host-specific and there are no earlier reports on C. aurantifolia. Therefore this should be new species of Prillieuxina based on morphology and host-specificity.

\section{Acknowledgements}

The authors thank to Dean, Faculty of Agriculture, Abhilashi University, Mandi as well as Head, Department of Botany, Abhilashi Institute of Life Sciences, Mandi for providing laboratory facilities and valuable support throughout the study. 


\section{References}

Arnaud G 1918 - Les Astérinées. Ann Écol Nat Agric Montpellier 16(1-4),127.

Gautam AK 2014 - Occurrence of black mildew on Aegle marmelos at Himachal Pradesh, India. International Jopurnal of Phytopathology 3(3), 161-162.

Gautam AK 2015 - Prillieuxina aeglicola sp. nov. (ascomycota), a new black mildew fungus from Himachal Pradesh, India. Current Research in Environmental \& Applied Mycology 5(1), 70-73.

Hansford CG 1961 - The Meliolineae. A monograph. Sydowia 2, 1-806.

Hofmann T.A. 2009 - Plant parasitic Asterinaceae and Microthyriaceae from the Neotropics (Panama).

The Faculty of Biological Sciences, Johann Wolfgang Goethe-University, Germany.

Hongsanan S, Li YM, Liu JK, Hofmann T, Piepenbring M, Bhat JD, Boonmee S, Doilom M, Singtripop C, Tian Q, Mapook A, Zeng XY, Bahkali AH, Xu JC, Mortimer PE, Wu XH, Yang JB, Hyde KD 2014 - Revision of the genera in Asterinales. Fungal Diversity 68(1), 1-68.

Hosagoudar V., Kapoor JN 1984 - New Technique of mounting Meliolaceous fungi. Indian Phytopathology 38, 548-549.

Hosagoudar VB 2012 - Asterinales of India. Mycosphere 2(5), 617-852.

Hosagoudar VB, Agarwal DK 2008 - Taxonomic studies of Meliolales. Identification Manual. International Book Distributors, DehraDun.

Index Fungorum 2016 - Index Fungorum. http://www.indexfungorum. Org, accessed 21 April 2016.

Jayasiri SC, Hyde KD, Ariyawansa HA, Bhat J, Buyck B, Cai L, Dai YC, Abd-Elsalam KA, Ertz D, Hidayat I, Jeewon R, Jones EBG, Bahkali AH, Karunarathna SC, Liu JK, Luangsa-ard JJ, Lumbsch HT, Maharachchikumbura SSN, McKenzie EHC, Moncalvo, JM, Ghobad-Nejhad M, Nilsson H, Pang KA, Pereira OL, Phillips AJL, Raspé O, Rollins AW, Romero AI, Etayo J, Selçuk F, Stephenson SL, Suetrong S, Taylor JE, Tsui CKM, Vizzini A, Abdel-Wahab MA, Wen TC, Boonmee S, Dai DQ, Daranagama DA, Dissanayake AJ, Ekanayaka AH, Fryar SC, Hongsanan S, Jayawardena RS, Li WJ, Perera RH, Phookamsak R, de Silva NI, Thambugala KM, Tian Q, Wijayawardene NN, Zhao RL, Zhao Q, Kang JC, Promputtha I. 2015 - The Faces of Fungi database: fungal names linked with morphology, phylogeny and human impacts. Fungal Diversity 74(1), 3-18.

Jayawardena RS, Ariyawansa HA, Singtripop C, Li YM, Yan J, Li X, Nilthong S, Hyde KD 2014 - A re-assessment of Elsinoaceae (Myriangiales, Dothideomycetes). Phytotaxa 176 (1), 120-138.

Penjor T, Mimura T, Matsumoto R, Yamamoto M, Nagano Y 2014 - Characterization of limes (Citrus aurantifolia) grown in Bhutan and Indonesia using high-throughput sequencing. Science Reporter 4, 4853; DOI: 10.1038/srep04853.

Schoch CL, Crous PW, Groenewald JZ, Boehm EWA, Burgess TI, de Gruyter J, de Hoog GS, Dixon LJ, Grube M, Gueidan C, Harada Y, Hatakeyama S, Hirayama K, Hosoya, Huhndorf SM, Hyde KD, Jones EBG, Kohlmeyer J, Kruys Å, Li YM, Lücking T, Lumbsch HT, Marvanová L, Mbatchou JS, McVay AH, Miller AN, Mugambi GK, Muggia L, Nelsen MP, Nelson P, Owensby CA, Phillips AJL, Phongpaichit S, Pointing SB, Pujade-Renaud V, Raja HA, Rivas Plata E, Robbertse B, Ruibal C, Sakayaroj J, Sano T, Selbmann L, Shearer CA, Shirouzu T, Slippers B, Suetrong S, Tanaka K, Volkmann-Kohlmeyer B, Wingfield MJ, Wood AR, Woudenberg JHC, Yonezawa H, Zhang Y, Spatafora JW 2009 - A class-wide phylogenetic assessment of Dothideomycetes. Studies in Mycology. 64, 1-15.

Tanaka TA 1959 - Revision of Assam citrus. Bulletin of the University of Osaka Prefecture, Series B9, 29-39. 